\title{
Boguslaw Bembenek
}

Politechnika Rzeszowska

e-mail: bogdanb@prz.edu.pl

\section{NADZÓR KLASTROWY W KSZTALTOWANIU BEZPIECZEŃSTWA EKONOMICZNEGO KLASTRA}

\section{CLUSTER GOVERNANCE IN SHAPING CLUSTER} ECONOMIC SECURITY

DOI: $10.15611 / \mathrm{pn} .2017 .487 .01$

JEL Classification: A11, D02, D23, D71, D81, D85, D91, G18, G34, L14, L26, M21

Streszczenie: Artykuł składa się z trzech integralnych części, w których przedstawiono istotę bezpieczeństwa ekonomicznego klastra, znaczenie nadzoru klastrowego dla zapewnienia tego typu bezpieczeństwa oraz podstawowe standardy zarządzania klastrem, które w sposób bezpośredni odnoszą się do nadzoru klastrowego. W opracowaniu podkreślono, że niejednorodny i złożony charakter bezpieczeństwa ekonomicznego i nadzoru klastrowego oraz różny sposób ich definiowania utrudnia ich pomiar i kwantyfikację. Nadzór klastrowy, stymulując transparentne zarządzanie klastrem, przyczynia się do poprawy aktywności ekonomicznej klastra i jego pozytywnego wizerunku. Jako instrument wewnętrznej i zewnętrznej kontroli sprawności zarządzania klastrem kształtuje bezpieczeństwo ekonomiczne klastra. Analiza wtórnych źródeł informacji wykazała, że polskie klastry różnią się między sobą pod względem spełnienia standardów zarządzania klastrem w obszarze nadzoru klastrowego.

Słowa kluczowe: klaster, nadzór klastrowy, bezpieczeństwo ekonomiczne, rozwój.

Summary: The article consists of three integral parts which present the significance of cluster economic security, the importance of cluster governance in assuring this type of security, and basic standards of cluster management, which directly relate to cluster governance. The article emphasises that heterogeneous and complex nature of economic security and cluster governance as well as various definitions of these terms hinder their measurement and quantification. Cluster governance, stimulating transparent cluster management, contributes to the improvement of cluster economic activity and its positive image. As an instrument of internal and external control of cluster management efficiency it shapes cluster economic security. The analysis of secondary sources has indicated that Polish clusters differ as regards meeting the standards of cluster management within cluster governance.

Keywords: cluster, cluster governance, economic security, development. 
Bogusław Bembenek

\section{Wstęp}

Współczesną gospodarkę rynkową charakteryzuje nasilanie się procesów integracji i sieciowania przedsiębiorstw. Efektem tych procesów jest powstawanie m.in. klastrów jako złożonych organizmów gospodarczych, obejmujących współpracujące i konkurujące ze sobą przedsiębiorstwa, podmioty sektora $\mathrm{B}+\mathrm{R}$, instytucje otoczenia biznesu, które pomimo przynależności do danego klastra zachowują swą podmiotowość i autonomię. Polskie klastry w dużym stopniu uzależnione są od aktywności swych koordynatorów (organizacji klastrowych). To oni pełnią szereg funkcji na rzecz rozwoju klastrów, typu: animacja procesów wewnętrznych, inicjacja i koordynacja działań w klastrze, identyfikacja potrzeb członków klastra, zapewnienie finansowania projektów klastra itp. Podejmowane działania koordynatora w procesie zarządzania klastrem zmieniają się wraz ze zmianą wewnętrznych i zewnętrznych uwarunkowań funkcjonowania i rozwoju klastra. Komisja Europejska już od kilku lat uważa, że dalsze kształtowanie publicznych mechanizmów dedykowanych potrzebom klastrów i ich wykorzystanie w procesie przemian, dokonujących się w gospodarce, wymaga doskonalenia i standaryzacji zarządzania klastrem. W odpowiedzi na to i inne wyzwania związane z polską polityką klastrową w 2014 roku opracowano standardy zarządzania polskim klastrem. Wśród 36 standardów znajdują się także te, które odnoszą się bezpośrednio do nadzoru klastrowego, ukierunkowanego na zapewnienie bezpieczeństwa ekonomicznego klastrów.

Dynamiczny wzrost zainteresowania nadzorem klastrowym ze strony organów władz publicznych na poziomie krajowym i europejskim był główną przesłanką $\mathrm{i}$ inspiracją do zbadania tego zagadnienia na gruncie nauk ekonomicznych. Celem artykułu jest charakterystyka istoty nadzoru klastrowego i jego znaczenia w procesie kształtowania bezpieczeństwa ekonomicznego klastra. W procesie badawczym poszukiwano odpowiedzi na następujące pytania:

- W jaki sposób definiowane jest współcześnie bezpieczeństwo ekonomiczne klastra i nadzór klastrowy?

- Dlaczego nadzór klastrowy jest wartościowy z punktu widzenia kształtowania bezpieczeństwa ekonomicznego klastra?

- Jakie są podstawowe wymagania w zakresie nadzoru klastrowego, określone w ramach standardów zarządzania polskim klastrem?

- Czy w polskich klastrach spełnione są podstawowe standardy nadzoru klastrowego i czy klastry różnią się między sobą w tym obszarze?

Punktem wyjścia w podjętych rozważaniach jest stwierdzenie znanego faktu, że wieloaspektowość procesu zarządzania klastrem wymaga przynajmniej częściowego odniesienia do współczesnych koncepcji sieci organizacyjnych, interesariuszy i społecznej odpowiedzialności. Przedstawione teoretyczne i praktyczne zagadnienia związane z podjętą tematyką są egzemplifikacją realnych zjawisk i procesów mających swoje potwierdzenie w praktyce zarządzania klastrem. Rozważania naukowe prowadzono na podstawie analizy literatury przedmiotu i danych zastanych. 


\section{Bezpieczeństwo ekonomiczne klastra}

Bezpieczeństwo ekonomiczne, chociaż jest analizowane od kilkunastu lat na gruncie ekonomii i nauk o bezpieczeństwie, to wciąż nie jest jednoznacznie zdefiniowane. Jest to związane z tym, że każda dziedzina nauki zajmuje się różnymi aspektami bezpieczeństwa [Węgrzyńska 2015, s. 263]. Ponadto pojęcie bezpieczeństwa zależne jest od wielu endo- i egzogenicznych czynników o charakterze obiektywnym i subiektywnym [Badak 2010, s. 138]. Poszczególne mniej lub bardziej szczegółowe określenia tego pojęcia różnią się zakresem i wagą postrzeganych zagrożeń [Plecka, Rychły-Lipińska 2013, s. 123].

Według E. Haliżaka ekonomiczny wymiar bezpieczeństwa jest efektem tego, że ekonomia przenika treść, struktury, oddziałuje na uwarunkowania oraz potrzeby i interesy bezpieczeństwa każdej organizacji [Bobrow, Haliżak, Zięba (red.) 1997, s. 77]. Warunkiem skutecznego kształtowania tego typu bezpieczeństwa w ramach danej organizacji jest jej suwerenność, czyli zdolność do samodzielnego, niezależnego od innych podmiotów zarządzania własnymi zasobami [Leszczyński 2016, s. 84].

Pojęcie bezpieczeństwa ekonomicznego klastra podkreśla współzależność między bezpieczeństwem a rozwojem klastra. Jest to pojęcie szerokie i wieloaspektowe, postrzegane z różnych perspektyw, które często bywa definiowane jako [Dziekański 2014, s. 122-123; Księżopolski 2011, s. 29-31; Plecka 2014, s. 187]:

- zdolność klastra do zaspokojenia podstawowych potrzeb jego członków w obszarze współpracy klastrowej,

- zdolność klastra do takiego wykorzystania zasobów, które gwarantuje jego niezagrożony rozwój,

- gwarancja rozwoju klastra poprzez sprawne zarządzanie finansami klastra,

- ogół decyzji finansowych w zakresie zarządzania rozwojem klastra,

- zdolność klastra do reagowania na zagrożenia, jakie stwarza otoczenie,

- zachowanie odpowiedniego potencjału klastra oraz aktywne przeciwdziałanie pojawiającym się kryzysom w poszczególnych fazach życia klastra,

- zdolność do efektywnego koordynowania współpracy projektowej w klastrze oraz utrzymania odpowiedniego poziomu integralności członków klastra,

- zdolność do ochrony lub promowania interesów ekonomicznych członków klastra pomimo niekorzystnych czynników otoczenia,

- działania podejmowane przez koordynatora klastra na rzecz zapewnienia trwałości rozwoju klastra i niezakłóconego funkcjonowania klastra pomimo potencjalnych problemów z finansowaniem projektów klastra.

W oparciu o wymienione definicje i atrybuty bezpieczeństwa ekonomicznego klastra można przyjąć, że klaster jako wewnętrznie zorganizowana grupa społeczna ukierunkowana biznesowo, działająca wspólnie według określonych wartości, reguł i zasad, aby móc sprawnie realizować określone cele, powinien wykazywać się zdolnością zapewnienia tego typu bezpieczeństwa i utrzymania go na odpowied- 
nim poziomie. Niezbędne jest w tym przypadku zmniejszenie prawdopodobieństwa wystąpienia zdarzeń, które mogą tworzyć potencjalne lub realne zagrożenie dla obecnego i przyszłego funkcjonowania klastra [Badak 2010, s. 140]. Oczywiście $\mathrm{w}$ aspekcie realizacji celów związanych $\mathrm{z}$ bezpieczeństwem ekonomicznym pomocna jest analiza strategiczna klastra. Ocena stanu bezpieczeństwa klastra skorelowana jest $\mathrm{z}$ aktualną jego sytuacją ekonomiczną, przez co wymaga posiadania dokładnej wiedzy o jego potencjale strategicznym i otoczeniu.

Pojęcie bezpieczeństwa ekonomicznego klastra odnosi się do bezpieczeństwa wewnętrznego i zewnętrznego klastra (tab. 1). Dotyczy decyzji operacyjnych, taktycznych i strategicznych w klastrze, mających zapewnić elastyczność współpracy klastrowej zgodnie z interesami członków klastra, harmonijny rozwój, niezakłócone funkcjonowanie klastra pomimo oddziaływania zagrożeń, jakie stwarza otoczenie. Satysfakcjonujący jego poziom determinowany jest w znacznej mierze sprawnością zarządzania klastrem i wymaga odpowiedniego wsparcia kluczowych interesariuszy wewnętrznych i zewnętrznych (tab. 1). Klastry o dużym potencjale strategicznym i sprawnie zarządzane mają większe możliwości przezwyciężania kryzysów, których przyczyny powstają w ich otoczeniu wewnętrznym i zewnętrznym.

Tabela 1. Podstawowe wymiary bezpieczeństwa ekonomicznego klastra

\begin{tabular}{|c|c|}
\hline \multicolumn{2}{|c|}{ BEZPIECZEŃSTWO EKONOMICZNE KLASTRA } \\
\hline wewnętrzne bezpieczeństwo klastra & zewnętrzne bezpieczeństwo klastra \\
\hline$\uparrow$ & $\uparrow$ \\
\hline $\begin{array}{l}\text { klaster poprzez swoje wewnętrzne instytucje } \\
\text { i sprawnie działające organy władzy i nadzoru } \\
\text { ma możliwość wzmacniania potencjału strate- } \\
\text { gicznego oraz neutralizowania zagrożeń nega- } \\
\text { tywnie wpływających na jego obecne i przyszłe } \\
\text { funkcjonowanie w otoczeniu }\end{array}$ & $\begin{array}{l}\text { kluczowi interesariusze zewnętrzni klastra } \\
\text { (organy władzy publicznej, inwestorzy i inni } \\
\text { partnerzy biznesowi) poprzez swoją aktywność } \\
\text { mają możliwość tworzenia szans rozwojowych } \\
\text { i neutralizacji zagrożeń negatywnie wpływają- } \\
\text { cych na działalność klastra }\end{array}$ \\
\hline $\begin{array}{l}\text { INTERESARIUSZE WEWNĘTRZNI } \\
\text { KLASTRA }\end{array}$ & $\begin{array}{c}\text { INTERESARIUSZE ZEWNĘTRZNI } \\
\text { KLASTRA }\end{array}$ \\
\hline
\end{tabular}

Źródło: opracowanie własne.

Jednym z celów strategicznych klastrów jest zapewnienie ich członkom bezpieczeństwa ekonomicznego poprzez kształtowanie odpowiednich warunków rozwoju. $Z$ uwagi na to, że jest to proces ciągły o dużej dynamice zmienności, ostateczny poziom tego bezpieczeństwa może być postrzegany zarówno przez pryzmat aktywności ich koordynatorów, członków, organów władzy i nadzoru klastra, jak i kluczowych interesariuszy zewnętrznych. Dla przykładu, interwencjonizm państwa w rozwój klastrów poprzez politykę klastrową w wielu przypadkach jest kluczowym czynnikiem stymulującym bezpieczeństwo ekonomiczne klastrów. Z jednej strony organy władz publicznych zapewniają mniej lub bardziej korzystne warunki rozwoju przedsiębiorczości, z drugiej zaś wymagają od organizacji klastrowych 
ciągłego doskonalenia, m.in. w obszarze kształtowania tego typu bezpieczeństwa (np. poprzez wypracowanie systemu samofinansowania klastrów).

W procesie zagwarantowania bezpieczeństwa ekonomicznego wartościowe mogą okazać się różne narzędzia, np. audyt, kontrola zarządcza, system kontroli wewnętrznej, nadzór klastrowy. Narzędzia te coraz częściej wykorzystywane są przez koordynatorów klastrów w zarządzaniu klastrami. Wynika to zarówno z potrzeby, jak i konieczności doskonalenia zarządzania klastrem.

\section{Nadzór klastrowy jako fundament bezpieczeństwa ekonomicznego klastra}

Koncepcja nadzoru klastrowego (cluster governance) powstała na podstawie koncepcji nadzoru korporacyjnego (corporate governance), która jest bardzo popularna na całym świecie i stanowi przedmiot rozważań na gruncie prawa, ekonomii, socjologii i nauk o zarządzaniu. Pomimo występujących pomiędzy nimi różnic, przyjmuje się, że obie te koncepcje są odzwierciedleniem nowych tendencji w postrzeganiu funkcjonowania organizacji społecznie odpowiedzialnych, w coraz większym stopniu uzależnionych od kluczowych interesariuszy.

Nadzór klastrowy (ład klastrowy, władztwo klastrowe, kontrola w klastrze) stał się obiektem szczególnego zainteresowania organów władz publicznych z chwilą, gdy skierowano do klastrów finansowe wsparcie z funduszy strukturalnych. Wynikało to z potrzeby kontroli, jak skutecznie i efektywnie realizowane są w klastrach projekty finansowane ze środków publicznych. Ponadto także inni kluczowi interesariusze, np. członkowie klastra, partnerzy biznesowi, inwestorzy, pracownicy, dążąc do ochrony własnych interesów, są zainteresowani mechanizmami, za pomocą których ustalane są cele klastra, środki ich realizacji i kontroli. Z założenia sprawny nadzór klastrowy ma służyć [Stępień 2016, s. 223; Herdan 2007, s. 28; Klepczarek 2016, s. 87-88; Ebbekink 2017, s. 621-639; Lund-Thomsen, Pillay 2012, s. 568-576]:

- usprawnieniu procesu podejmowania decyzji w klastrze i analizy osiągniętych wyników klastra, sprzyjając jednocześnie racjonalnemu pozyskiwaniu i wykorzystaniu posiadanych zasobów,

- kształtowaniu procesów decyzyjnych, zwłaszcza w obszarach strategicznych, aby podejmowane decyzje w klastrze odzwierciedlały interesy różnych interesariuszy wewnętrznych i zewnętrznych,

- zabezpieczeniu interesów członków klastra, inwestorów, partnerów publicznych, inwestujących w rozwój klastra odpowiednie środki oraz oczekujących konkretnych efektów materialnych i niematerialnych,

- ochronie członków klastra przed nieprawidłowym i nieetycznym działaniem koordynatora i menedżera klastra, którzy mogą realizować własne interesy sprzeczne z celami klastra, 
- regulowaniu relacji w klastrze pomiędzy wszystkimi kluczowymi interesariuszami wewnętrznymi i zewnętrznymi zaangażowanymi w funkcjonowanie klastra w oparciu o formalne i nieformalne reguły działania,

- poprawie kondycji finansowej klastra (środki przeznaczane na działalność operacyjną koordynatora klastra oraz realizację projektów w klastrze).

Wymienione zadania nadzoru klastrowego są spójne z trzema podstawowymi jego funkcjami, takimi jak: kontrolno-regulacyjna, koordynacyjna oraz motywacyjno-poznawcza [Berthinier-Poncet 2013, s. 7]. Potwierdza to jednoznacznie, że koncepcja nadzoru klastrowego odnosi się w znacznej mierze do instytucjonalnych aspektów funkcjonowania klastra [Werf 2015, s. 18].

Tabela 2. Definicje nadzoru klastrowego

\begin{tabular}{|c|c|}
\hline Lp. & Nadzór klastrowy \\
\hline D1 & $\begin{array}{l}\text { Mechanizm wykorzystywany do kontrolowania i koordynowania zachowań koordynatora, } \\
\text { członków i partnerów klastra, którzy współpracują z kadrą zarządzającą klastrem dla spraw- } \\
\text { nej realizacji celów klastra. }\end{array}$ \\
\hline D2 & $\begin{array}{l}\text { Instytucja, która służy do kontroli różnych aspektów zarządzania klastrem przez kluczowych } \\
\text { interesariuszy wewnętrznych (członków klastra, pracowników) i zewnętrznych (partnerów } \\
\text { biznesowych, organy władzy publicznej, instytucje wsparcia biznesu itp.), którzy z różnych } \\
\text { przyczyn są zainteresowani aktywnością klastra. }\end{array}$ \\
\hline D3 & Instytucja, która promuje uczciwość, odpowiedzialność i przejrzystość w klastrze. \\
\hline D4 & $\begin{array}{l}\text { Mechanizm, który umożliwia członkom klastra i innym partnerom kontrolę wykorzystania } \\
\text { zainwestowanego przez nich kapitału w klastrze. }\end{array}$ \\
\hline D5 & $\begin{array}{l}\text { System oceny działalności jednostek zarządzających klastrem pod względem rozwoju i kre- } \\
\text { owania wartości dla interesariuszy klastra. }\end{array}$ \\
\hline D6 & $\begin{array}{l}\text { Sposób, w jaki menedżer klastra odpowiada przed członkami klastra i innymi kluczowymi } \\
\text { interesariuszami (organami władzy publicznej, bankami, inwestorami itp.) oraz kształtuje } \\
\text { strukturę organizacyjną, sprzyjającą sprawnej realizacji celów klastra. }\end{array}$ \\
\hline D7 & System sprzyjający sprawnemu zarządzaniu klastrem i sprawnej jego kontroli. \\
\hline D8 & $\begin{array}{l}\text { Mechanizmy, struktury i procesy wewnętrznej kontroli klastra w celu zapewnienia } \\
\text { zgodności jego działania z interesem kluczowych interesariuszy klastra. }\end{array}$ \\
\hline D9 & $\begin{array}{l}\text { Szeroko rozumiana kontrola nad klastrem, wynikająca nie tylko z potrzeby/konieczności } \\
\text { określonej przez organy władzy i nadzoru w klastrze, ale także inicjowana przez zewnętrz- } \\
\text { nych kluczowych interesariuszy w określonym wymiarze i zakresie. }\end{array}$ \\
\hline D10 & $\begin{array}{l}\text { System obejmujący zasady, mechanizmy i procedury gwarantujące prawidłowe zarządzanie } \\
\text { klastrem poprzez zatrudnienie przez koordynatora klastra (organizację klastrową) profesjo- } \\
\text { nalnego menedżera klastra, który powinien działać zgodnie z obowiązującymi w klastrze } \\
\text { zasadami i wartościami oraz interesami członków klastra. }\end{array}$ \\
\hline
\end{tabular}

Źródło: opracowanie własne na podstawie [Ebbekink 2017, s. 621-639; Krzysztofek 2012, s. 334; Herdan 2007, s. 28-30; Dube i in. 2015, s. 105; Mikhaylov 2013, s. 92-95].

Definicje nadzoru klastrowego przedstawione w tab. 2 wskazują, że termin ten dotyczy zarówno formalnego systemu odpowiedzialności kadry zarządzającej klastrem przed organami władzy i nadzoru klastra oraz jego członkami, jak i szerszych powiązań formalnych i nieformalnych kadry zarządzającej klastrem z orga- 
nami władzy w klastrze, członkami klastra i innymi kluczowymi interesariuszami (np. organami władzy publicznej, inwestorami, partnerami biznesowymi itp.). Istniejące różnice w definiowaniu tego pojęcia są efektem tego, że współczesne klastry tworzą płaszczyznę współpracy i konkurencji, na której ścierają się interesy różnych grup interesariuszy klastra [Kuciński 2013, s. 225].

Według grupy ekspertów PwC (Pricewaterhouse Coopers) nadzór klastrowy, który nie jest jednoznaczny z zarządzaniem klastrem, odnosi się do zamierzonych i planowanych działań zbiorowych interesariuszy klastra w celu przyspieszenia rozwoju klastra i zapewnienia mu względnie trwałej przewagi konkurencyjnej. Z uwagi na to, że klastry zazwyczaj napędzane są wyłącznie wysiłkami ich menedżerów, tym bardziej bez wspólnego zaangażowania interesariuszy działanie klastra skazane jest na niepowodzenie [Schretlen i in. 2011, s. 21].

Należy podkreślić, że nadzór klastrowy jest pojęciem szerszym od pojęcia nadzoru członkowskiego. W przypadku nadzoru członkowskiego nadzór nad klastrem sprawowany jest wyłącznie przez interesariuszy wewnętrznych klastra (członków, organy władzy i nadzoru klastra, pracowników). Z kolei nadzór klastrowy sprawowany jest zarówno przez kluczowych interesariuszy wewnętrznych, jak i zewnętrznych, zainteresowanych $\mathrm{w}$ różnym stopniu sprawnością zarządzania klastrem. Według L. Knop nadzór klastrowy składa się z wybranych i zaangażowanych przedstawicieli wielu środowisk (biznesu, nauki, administracji, społeczeństwa obywatelskiego), którzy dbają o realizację celów klastra i ją weryfikują na podstawie oceny stopnia zrównoważonego rozwoju trzech komponentów [Knop 2013, s. 308]:

- wiedzy jako fundamentu wartości i rozwoju klastra,

- struktury jako fundamentu koordynacji i konfiguracji zasobów klastra,

- zaufania jako fundamentu stabilizacji i trwałości relacji w klastrze.

Podstawowymi aspektami nadzoru klastrowego są materia nadzoru i tworzenie relacji klastra z interesariuszami. Materia nadzoru dotyczy mechanizmów, zasad, procedur i regulacji o charakterze ekonomicznym i prawnym (np. wewnętrzne statuty, regulaminy, kodeksy etyczne, regulacje Unii Europejskiej). Z kolei tworzenie relacji klastra $\mathrm{z}$ interesariuszami ma na celu kształtowanie odpowiednich warunków funkcjonowania i rozwoju klastra w otoczeniu [Żabski 2013, s. 133].

L. Knop konstatuje, że działania nadzorujące klaster opierają się na dwóch kluczowych przesłankach - paradygmacie sieciowym i teorii interesariuszy [Knop 2013, s. 304, 307-308]. Tym samym w procesie budowania systemu nadzoru klastrowego niezbędne jest holistyczne podejście do zarządzania klastrem jako samoorganizującą się siecią strategiczną, koncepcji nadzoru korporacyjnego, koncepcji zarządzania relacjami z interesariuszami i związanej z nią w sposób bezpośredni społecznej odpowiedzialności (CSR - Corporate Social Responsibility). W związku $\mathrm{z}$ dynamicznym rozwojem klastrów niezbędne jest stworzenie w klastrach sprawnego systemu nadzoru klastrowego, który zapewni przejrzystość procesów i działań zachodzących w tych strukturach. Każdy klaster ma pełną autonomię w zakresie formalizacji nadzoru klastrowego, kierując się najczęściej swymi aktualnymi we- 
wnętrznymi i zewnętrznymi uwarunkowaniami rozwoju. Przedstawiciele organów władzy i członkowie klastra powinni wspólnie określić model nadzoru klastrowego, adekwatny do potrzeb i możliwości klastra. W jego kształtowaniu niezbędne jest wskazanie odpowiedzi na następujące kluczowe pytania:

- Kto i w jakim zakresie jest uprawniony do podejmowania i nadzorowania decyzji w klastrze?

- Kto ustala procedury powoływania i odwoływania członków organów władzy i nadzoru w klastrze i w jaki sposób?

- Jakie podstawowe standardy powinny był spełnione w zarządzaniu klastrem i nadzorze klastrowym?

- Jakie działania powinny być systematycznie podejmowane w stosunku do interesariuszy wewnętrznych i zewnętrznych w ramach społecznej odpowiedzialności klastra?

- Jakiego rodzaju informacje mogą być przekazywane interesariuszom wewnętrznym i zewnętrznym i w jakiej formie?

- Czy przyjęte określone zasady nadzoru klastrowego sprzyjają usprawnianiu procesu podejmowania decyzji i efektywnej alokacji władzy w klastrze?

- Czy model nadzoru klastrowego służy budowaniu zaufania społecznego i kształtowaniu pozytywnego wizerunku klastra?

Prawidłowo opracowany system nadzoru klastrowego zawiera mechanizmy, formalne i nieformalne zasady oraz procedury działania, które pozwalają organom decyzyjnym i nadzorczym w klastrze podejmować właściwe decyzje zgodne z interesami kluczowych interesariuszy wewnętrznych i zewnętrznych. Ponadto identyfikuje prawa i obowiązki, legitymizuje działania i determinuje odpowiedzialność [Walczak 2012, s. 191]. Skuteczność podejmowanych działań w tym obszarze wymaga nade wszystko przestrzegania podstawowych zasad nadzoru klastrowego, takich jak [Knop 2013, s. 311-312; Schretlen i in. 2011, s. 21-26]:

- przejrzysty i powszechnie akceptowany podział uprawnień i obowiązków dla organów zarządczych, doradczych i nadzorczych w klastrze,

- odpowiedzialność klastra w wymiarze ekonomicznym, społecznym i ekologicznym (CSR),

- wysokie standardy etyczne,

- uczciwe działanie koordynatora klastra w interesie jego członków,

- integracja i zaangażowanie członków wokół wspólnych celów klastra,

- transparentność finansowania aktywności klastra,

- ujawnianie aktualnych i potencjalnych konfliktów interesów w klastrze,

- właściwa, otwarta i rzetelna komunikacja klastra z interesariuszami,

- systematyczny niezależny audyt wewnętrzny i zewnętrzny klastra,

- monitoring i ewaluacja sprawności zarządzania klastrem.

Szeroki zakres problematyki nadzoru klastrowego oraz różnorodność klastrów powodują, że określenie mechanizmów, zasad i procedur gwarantujących sprawne funkcjonowanie klastra jest istotnym wyzwaniem. Wprowadzane w klastrze stan- 
dardy i zasady nadzoru klastrowego powinny być na tyle elastyczne, by możliwa była ich adaptacja do zmian uwarunkowań rozwoju klastra.

\section{Standardy zarządzania klastrem dotyczące nadzoru klastrowego - w kontekście wyników badań Polskiej Agencji Rozwoju Przedsiębiorczości}

Polska Agencja Rozwoju Przedsiębiorczości (PARP) w 2014 roku określiła 36 standardów zarządzania klastrem ${ }^{1}$. Co najmniej 12 z nich dotyczy w sposób bezpośredni nadzoru klastrowego, gdyż są zgodne z podstawowymi jego zasadami. Ich celem jest stymulowanie koordynatorów klastrów do osiągania doskonałości w procesie zarządzania klastrem. Zgodnie z przyjętymi standardami nadzoru klastrowego w klastrze należy [Piotrowski 2015, s. 14-20, 26-29; Kępka, Kacperek 2017, S. 22-48]:

- zdefiniować zakres obowiązków i uprawnień koordynatora klastra,

- określić kształt struktury organizacyjnej klastra,

- opracować i wdrażać strategię rozwoju klastra,

- wdrożyć koncepcję społecznej odpowiedzialności klastra,

- wdrożyć system zarządzania jakością w organizacji klastrowej,

- opracować aktualną bazę danych członków klastra,

- wykorzystywać różnorodne narzędzia i formy komunikacji,

- zapobiegać konfliktom interesu w klastrze,

- opracować realny plan finansowy klastra,

- zapewnić transparentność operacji finansowych i ich zgodność z przyjętym planem finansowym klastra,

- prowadzić monitoring i ewaluację realizacji strategii rozwoju klastra,

- dokonać kompleksowej oceny zgodności działań podejmowanych przez koordynatora klastra z wewnętrznymi regulacjami klastra.

Stworzenie ram organizacyjnych i prawnych koordynatora klastra, w tym określenie zakresu jego obowiązków i uprawnień wynikających z pełnionej funkcji, jest jednym z głównych czynników rozwoju klastra. Brak podstaw organizacyjnych działania koordynatora klastra często rodzi wiele problemów operacyjnych i uniemożliwia sprawny rozwój klastra. Oczywiście zakres obowiązków i uprawnień koordynatora klastra zmienia się wraz ze zmianą uwarunkowań rozwoju klastra, w tym jego fazy życia. W procesie oceny spełnienia tego standardu zarządzania uwzględnia się, czy w klastrze określono formalny zakres obowiązków i uprawnień jego koordynatora (np. w umowie, statucie, regulaminie, odrębnym dokumencie itp.) i czy jest on zatwierdzony przez członków klastra oraz jego organy władzy

1 W 2016 roku w PARP dokonano drobnej modyfikacji standardów zarządzania klastrem, aby były bardziej adekwatne do specyfiki polskich klastrów. Połączono m.in. standard opracowywania planu finansowego ze standardem transparentności operacji finansowych [Frączek, Kryjom 2016a, s. 3]. 
i nadzoru. Standard ten jest obligatoryjny dla klastrów embrionalnych, wzrostowych i dojrzałych.

Kolejnym standardem zarządzania klastrem odnoszącym się do nadzoru klastrowego i dotyczącym podstaw organizacyjnych działania klastra jest poprawne określenie struktury organizacyjnej klastra, adekwatnej do specyfiki klastra i jego celów. Struktura organizacyjna klastra powinna ustalać relacje pomiędzy koordynatorem, członkami i organami klastra. Koordynator klastra powinien dysponować schematem organizacyjnym, zawierającym szczegółowy opis komórek organizacyjnych oraz wewnętrznego układu hierarchicznego lub heterarchicznego klastra. Przyjęto, że ten standard stymuluje nadzór i efektywne zarządzanie klastrem, zgodnie z interesami jego członków i innych kluczowych interesariuszy. Przedmiotem oceny spełnienia standardu jest dokument zatwierdzony przez członków oraz organy decyzyjne klastra, który określa kształt i charakter struktury organizacyjnej klastra. Standard jest obligatoryjny dla każdego klastra, niezależnie od jego fazy życia.

W nadzorze klastrowym bardzo użytecznym instrumentem jest także opracowana strategia rozwoju klastra w modelu partycypacyjnym (przy aktywnym udziale kluczowych wewnętrznych interesariuszy klastra), określająca m.in. misję, wizję, kierunki rozwoju, cele strategiczne klastra i sposoby ich urzeczywistnienia. Stanowi ona podstawę rozliczenia aktywności jednostek zarządzających klastrem i członków klastra w zakresie realizacji wspólnych celów współpracy klastrowej. Przyjęto, że działania koordynatora i członków klastra powinny być zgodne z przyjętą strategią rozwoju, sama zaś strategia powinna być elastycznie weryfikowana i aktualizowana, gdy pojawi się taka potrzeba czy konieczność. Przedmiotem oceny stopnia spełnienia tego standardu zarządzania jest sformalizowana aktualna strategia klastra zatwierdzona przez jego interesariuszy wewnętrznych, opracowana z ich udziałem i weryfikowana wraz ze zmianą uwarunkowań. Standard jest obligatoryjny dla klastrów embrionalnych, wzrostowych i dojrzałych.

Fundamentem nadzoru klastrowego jest koncepcja społecznej odpowiedzialności klastra. Tym samym przyjęto, że strategia rozwoju klastra powinna uwzględniać główne założenia tego typu odpowiedzialności. Koordynator klastra powinien podejmować działania na rzecz promocji i sprawnego wdrażania zasad tej koncepcji w praktyce działania członków klastra. Częstotliwość i forma podejmowanych działań w tym obszarze powinna być adekwatna do fazy życia klastra, jego branży oraz indywidualnych potrzeb i możliwości jego członków. Standard jest opcjonalny dla klastrów embrionalnych, obligatoryjny zaś dla wzrostowych i dojrzałych.

Nadzór klastrowy wymaga odpowiednio wdrożonego systemu zarządzania jakością w organizacji klastrowej. W tym przypadku standard zarządzania klastrem jest spełniony, gdy koordynator posiada wdrożony system zarządzania jakością i/lub przeprowadza systematycznie badania postrzegania przez członków klastra jakości dostarczanych przez siebie usług na rzecz rozwoju klastra oraz badania satysfakcji członkowskiej. Standard jest opcjonalny dla klastrów embrionalnych i wzrostowych, obligatoryjny zaś dla klastrów dojrzałych. 
Kolejny standard zarządzania klastrem w zakresie nadzoru klastrowego dotyczy aktualnej bazy danych członków klastra. Opracowana poprawnie i w miarę możliwości szczegółowa tego typu baza danych z założenia ma ułatwić bieżące wykorzystywanie danych w podejmowaniu decyzji, przyśpieszyć proces sieciowania w wymiarze krajowym i międzynarodowym, a także usprawnić proces weryfikacji aktywności klastra i jego koordynatora przez partnerów publicznych (np. Ministerstwo Rozwoju, PARP, organy władzy samorządowej). Przyjęto, że podstawowe dane dotyczące członków klastra powinny mieć charakter jawny i być udostępnione publicznie poprzez stronę internetową klastra i/lub jego koordynatora. Standard jest obligatoryjny dla klastrów embrionalnych, wzrostowych i dojrzałych.

Sprawny system nadzoru klastrowego wymaga wykorzystywania w klastrze różnych narzędzi i form komunikacji. W standardzie przyjęto, że częstotliwość, formę i zasięg komunikacji należy dostosować do realizowanych działań, potrzeb informacyjno-komunikacyjnych, uwarunkowań rozwoju klastra. Jednak minimum raz w roku powinno odbyć się spotkanie członków z przedstawicielami organów decyzyjnych i kontrolnych klastra. Standard jest obligatoryjny dla wszystkich klastrów.

Niezmiernie istotną kwestią w zakresie nadzoru klastrowego jest zapobieganie potencjalnym konfliktom interesu w klastrze $\mathrm{i}$ ich rozwiązywanie w oparciu o wewnętrzne mechanizmy (instytucje) w klastrze. Jest to szczególnie ważne, zważywszy na strukturę członków klastra, w której współpracują także konkurenci (koopetycja). Innym źródłem potencjalnego konfliktu może być oportunistyczne zachowanie koordynatora klastra, który wykorzystując swoją uprzywilejowaną pozycję w klastrze, dąży do osiągnięcia wyłącznie indywidualnych korzyści. Przedmiotem oceny stopnia spełnienia tego standardu zarządzania są przede wszystkim wewnętrzne regulacje klastra, które zapobiegają tego typu konfliktom w klastrze i pomagają sprawnie nimi zarządzać, jeżeli się pojawią, np. pomiędzy koordynatorem a członkami klastra lub też pomiędzy samymi członkami klastra. I w tym przypadku standard jest obligatoryjny dla wszystkich klastrów, bez względu na ich fazę życia.

Opracowany kompletny, wiarygodny i realny plan finansowy klastra powinien uwzględniać przewidywane dochody i wydatki, inwestycje związane z celami określonymi w strategii rozwoju klastra. Ten standard zarządzania klastrem, szczególnie istotny w obszarze nadzoru klastrowego, ponownie jest obligatoryjny dla klastrów embrionalnych, wzrostowych i dojrzałych.

Nadzór klastrowy wymaga zapewnienia odpowiedniego poziomu transparentności operacji finansowych i zgodności z planem finansowym. Koordynator klastra spełnia ten standard, gdy po zakończeniu roku obrachunkowego przedstawia członkom klastra finalne zestawienie przychodów i poniesionych kosztów wynikających z przyjętego planu finansowego. Wymagane jest zatwierdzenie opracowanego sprawozdania finansowego przez interesariuszy wewnętrznych klastra. Standard jest obligatoryjny dla wszystkich klastrów, niezależnie od ich fazy życia. 
Strategicznym narzędziem nadzoru klastrowego jest monitoring i ewaluacja realizacji strategii rozwoju klastra. Przyjęto, że standard zarządzania w tym zakresie jest spełniony, gdy koordynator klastra dysponuje odpowiednio opracowanymi mechanizmami i wskaźnikami monitorowania i ewaluacji, adekwatnymi do potrzeb i specyfiki klastra. Ponadto niezbędne jest cykliczne prowadzenie tego typu kontroli i prezentowanie jej wyników kluczowym interesariuszom wewnętrznym, tak by na tej podstawie mogły powstawać propozycje zmian w klastrze. Standard jest opcjonalny tylko dla klastrów embrionalnych, obligatoryjny zaś dla wzrostowych i dojrzałych.

W nadzorze klastrowym niezbędna jest cykliczna ocena aktywności koordynatora klastra pod względem jej zgodności z przyjętymi regulacjami wewnętrznymi, np. ze strategią, statutem, regulaminem, umową, kodeksem etycznym itp. Ten standard zarządzania klastrem jest spełniony, gdy przynajmniej raz w roku interesariusze wewnętrzni klastra oceniają aktywność swego koordynatora przyjętą metodą oceny. Standard jest obligatoryjny tylko dla klastrów wzrostowych i dojrzałych.

W 2015 roku PARP przeprowadziła ogólnopolską weryfikację stopnia zgodności zarządzania klastrami w odniesieniu do opracowanych w 2014 roku standardów zarządzania klastrem [Frączek, Kryjom 2016b, s. 6-54]. Badania zrealizowano na podstawie wywiadu indywidualnego pogłębionego oraz narzędzia do autoewaluacji 64 koordynatorów klastrów ze wszystkich województw kraju, gdzie 5 klastrów - znajdowało się w fazie embrionalnej (klastry embrionalne), 58 - w fazie wzrostu/ rozwoju (klastry wzrostowe), a tylko 1 - w fazie dojrzałości (klaster dojrzały).

$\mathrm{Z}$ badań wynikało, że w badanym klastrze dojrzałym spełniono prawie wszystkie standardy w zakresie nadzoru klastrowego (tab. 3).

Najczęściej zidentyfikowane słabe strony nadzoru klastrowego w badanych klastrach dotyczyły takich standardów, jak [Frączek, Kryjom 2016b, s. 32-54]:

- w klastrze dojrzałym - mechanizmy zapobiegania konfliktom w klastrze i ich rozwiązywania, system zarządzania jakością w organizacji klastrowej, w tym cykliczna ocena jakości usług koordynatora przez członków klastra,

- w klastrach wzrostowych - transparentność operacji finansowych i ich zgodność z planem finansowym klastra, system zarządzania jakością w organizacji klastrowej, plan finansowy klastra, monitoring i ewaluacja strategii,

- w klastrach embrionalnych - strategia rozwoju i realny plan finansowy klastra, monitoring i ewaluacja strategii klastra, transparentność operacji finansowych i ich zgodność z planem finansowym klastra, ocena zgodności aktywności koordynatora klastra z wewnętrznymi regulacjami.

Generalnie słabe strony klastrów embrionalnych związane były z krótkim okresem funkcjonowania współpracy klastrowej i aktywności koordynatorów tych klastrów. Badani koordynatorzy podkreślali, że na tym etapie rozwoju klastra ocena realizacji planu finansowego na podstawie rocznego sprawozdania finansowego jest trudnym wyzwaniem. W ich opinii ich klastrom bardziej potrzebny jest dobry plan działania niż typowy plan finansowy. Niespełnienie standardu transparentnoś- 
Tabela 3. Ocena zgodności istniejącego systemu nadzoru klastrowego w badanych klastrach ze standardami zarządzania klastrem $(\mathrm{N}=64)$

\begin{tabular}{|c|c|c|c|}
\hline $\begin{array}{l}\text { Standardy zarządzania klastrem } \\
\text { w obszarze nadzoru klastrowego }\end{array}$ & $\begin{array}{c}\text { Klastry } \\
\text { embrionalne } \\
n=5\end{array}$ & $\begin{array}{c}\text { Klastry } \\
\text { wzrostowe } \\
n=58\end{array}$ & $\begin{array}{c}\text { Klastry } \\
\text { dojrzałe } \\
n=1\end{array}$ \\
\hline $\begin{array}{l}\text { S1: zdefiniowany zakres obowiązków } \\
\text { i uprawnień koordynatora klastra }\end{array}$ & $\begin{array}{c}5^{*} \\
\text { SOB }\end{array}$ & $\begin{array}{l}57 * 1 * * \\
\text { SOB }\end{array}$ & $\begin{array}{c}1 * \\
\text { SOB }\end{array}$ \\
\hline $\begin{array}{l}\text { S2: określona struktura organizacyjna } \\
\text { klastra }\end{array}$ & $\begin{array}{c}5^{*} \\
\text { SOB }\end{array}$ & $\begin{array}{l}57 * 1 * * \\
\text { SOB }\end{array}$ & $\begin{array}{l}1 * \\
\text { SOB }\end{array}$ \\
\hline $\begin{array}{l}\text { S3: opracowana i realizowana strategia } \\
\text { rozwoju klastra }\end{array}$ & $\begin{array}{c}2 * 3 * * \\
\text { SOB }\end{array}$ & $\begin{array}{c}50 * 8 * * \\
\text { SOB }\end{array}$ & $\begin{array}{c}1 * \\
\mathrm{SOB}\end{array}$ \\
\hline S4: społeczna odpowiedzialność klastra & $3 * 2 * *$ & $\begin{array}{c}53 * 5^{* *} \\
\text { SOB }\end{array}$ & $\begin{array}{c}1 * \\
\mathrm{SOB}\end{array}$ \\
\hline $\begin{array}{l}\text { S5: wdrożenie systemu zarządzania jako- } \\
\text { ścią w organizacji klastrowej }\end{array}$ & $4 * 1 * *$ & $43 * 15 * *$ & $\begin{array}{c}1 * * \\
\mathrm{SOB} \\
\end{array}$ \\
\hline $\begin{array}{l}\text { S6: opracowana aktualna baza danych } \\
\text { członków klastra }\end{array}$ & $\begin{array}{l}3 * 2 * * \\
\text { SOB }\end{array}$ & $\begin{array}{l}57 * 1 * * \\
\text { SOB }\end{array}$ & $\begin{array}{c}1 * \\
\mathrm{SOB}\end{array}$ \\
\hline $\begin{array}{l}\text { S7: stosowanie różnych narzędzi i form } \\
\text { komunikacji w klastrze }\end{array}$ & $\begin{array}{c}5^{*} \\
\text { SOB } \\
\end{array}$ & $\begin{array}{l}58^{*} \\
\mathrm{SOB}\end{array}$ & $\begin{array}{c}1 * \\
\mathrm{SOB} \\
\end{array}$ \\
\hline $\begin{array}{l}\text { S8: zapobieganie konfliktom interesu } \\
\text { w klastrze }\end{array}$ & $\begin{array}{c}5^{*} \\
\text { SOB } \\
\end{array}$ & $\begin{array}{c}54 * 4 * * \\
\text { SOB }\end{array}$ & $\begin{array}{c}1 * * \\
\mathrm{SOB} \\
\end{array}$ \\
\hline $\begin{array}{l}\text { S9: opracowanie realnego planu finanso- } \\
\text { wego klastra }\end{array}$ & $\begin{array}{l}2 * 3 * * \\
\text { SOB }\end{array}$ & $\begin{array}{l}45^{*} 13^{* *} \\
\text { SOB }\end{array}$ & $\begin{array}{c}1 * \\
\mathrm{SOB} \\
\end{array}$ \\
\hline $\begin{array}{l}\text { S10: zapewnienie transparentności operacji } \\
\text { finansowych i zgodności z planem finanso- } \\
\text { wym klastra }\end{array}$ & $\begin{array}{c}1 * 4 * * \\
\text { SOB }\end{array}$ & $\begin{array}{l}42 * 16^{* *} \\
\text { SOB }\end{array}$ & $\begin{array}{c}1 * \\
\mathrm{SOB}\end{array}$ \\
\hline $\begin{array}{l}\text { S11: prowadzenie monitoringu i ewaluacji } \\
\text { realizacji strategii rozwoju klastra }\end{array}$ & $5 * *$ & $\begin{array}{l}47 * 11 * * \\
\text { SOB }\end{array}$ & $\begin{array}{c}1 * \\
\mathrm{SOB}\end{array}$ \\
\hline $\begin{array}{l}\text { S12: kompleksowa ocena zgodności ak- } \\
\text { tywności koordynatora klastra z wewnętrz- } \\
\text { nymi regulacjami klastra }\end{array}$ & $2 * 3 * *$ & $\begin{array}{l}57 * 1 * * \\
\text { SOB }\end{array}$ & $\begin{array}{c}1 * \\
\text { SOB }\end{array}$ \\
\hline
\end{tabular}

Legenda: * standard spełniony, $* *$ standard niespełniony, SOB - standard obligatoryjny

Źródło: opracowanie własne na podstawie [Frączek, Kryjom 2016b, s. 30-54].

ci operacji finansowych było najczęściej konsekwencją braku planu finansowego klastra.

W żadnej badanej organizacji klastrowej nie wdrożono w pełni zaleceń normy ISO $26000^{2}$. Ponadto stwierdzono, że bezpośrednie odniesienie do poszczególnych

2 Norma ISO 26000 była opracowana przez Międzynarodową Organizację Standaryzacyjną w 2010 roku jako przewodnik w zakresie stosowania zasad odpowiedzialności społecznej i środowiskowej. W Polsce norma ta funkcjonuje od 2012 roku i wskazuje na potrzebę przejrzystego oraz etycznego zachowania w takich obszarach, jak np.: nadzór organizacyjny, praktyki z zakresu BHP, zagadnienia konsumenckie, zaangażowanie społeczne i rozwój społeczności lokalnej. Norma nie podlega certyfikacji, gdyż jest zbiorem praktyk i standardów przeznaczonych do dobrowolnego ich stosowania w różnych typach organizacji [http://odpowiedzialnybiznes.pl]. 
założeń koncepcji społecznej odpowiedzialności biznesu w strategiach rozwoju klastrów - nie jest powszechną dobrą praktyką [Frączek, Kryjom 2016b, s. 28-37].

Przeprowadzone badania pozwoliły także na zidentyfikowanie mocnych stron w zakresie nadzoru klastrowego. W większości badanych klastrów wykorzystywano szeroki wachlarz narzędzi i form komunikacji, określony był zakres obowiązków i uprawnień ich koordynatorów oraz określona była ich struktura organizacyjna.

$\mathrm{Z}$ pewnością usprawnianie nadzoru klastrowego w badanych klastrach należy rozpocząć od zapewnienia należytego poziomu transparentności operacji finansowych i ich zgodności z planem finansowym, wdrożenia systemu zarządzania jakością w organizacji klastrowej, opracowania realnego planu finansowego, prowadzenia cyklicznego monitoringu i ewaluacji realizacji strategii rozwoju klastra. Koordynatorzy klastrów powinni zadbać o wdrożenie pozytywnych zmian w tym obszarze, tak aby przekształcić istniejące słabe strony nadzoru klastrowego w mocne strony, które pozwolą zwiększyć poziom bezpieczeństwa ekonomicznego klastrów.

\section{Zakończenie}

Analiza wtórnych źródeł informacji wykazała, że implementacja nadzoru klastrowego w polskich klastrach stanowi obiektywną konieczność, a nie swoistą modę. Jest to $\mathrm{w}$ znacznej mierze związane $\mathrm{z}$ opracowanymi standardami zarządzania klastrem, które dotyczą tego obszaru. Standardy te z założenia mają być użyteczne w osiąganiu doskonałości w zarządzaniu klastrem. Przedstawiciele organów władzy publicznej zainicjowali proces standaryzacji zarządzania klastrem, aby skuteczniej minimalizować i nadzorować ryzyko związane z inwestowaniem środków publicznych w rozwój klastrów, usprawnić system wewnętrznego nadzoru, chronić inwestorów prywatnych i tym samym zwiększyć bezpieczeństwo ekonomiczne klastrów.

Klastry w Polsce różnią się między sobą ze względu na nadzór klastrowy. W wielu klastrach wysoki poziom zgodności nadzoru klastrowego ze standardami zarządzania klastrem świadczy zapewne o świadomości organów władzy w klastrze, że brak tego typu nadzoru mógłby poważnie zagrozić stabilności funkcjonowania klastra oraz kształtowaniu zaufania $w$ relacjach $\mathrm{z}$ interesariuszami wewnętrznymi i zewnętrznymi. Chęć zwiększania przejrzystości podejmowanych decyzji i wzmacniania wewnętrznego nadzoru klastrowego wzrasta wraz z rozwojem klastrów i jest wyraźnie widoczna w klastrach wzrostowych i dojrzałych. Można więc sądzić, że obserwowany wzrost zainteresowania pluralistycznej społeczności klastrowej standardami zarządzania klastrem niewątpliwie będzie stymulował dalszą dynamikę zmian w tym obszarze. Ponadto na tle doświadczeń polskiego klasteringu i w odniesieniu do uzyskanych wyników badań nie sposób nie zauważyć, że:

- nadzór klastrowy bywa regulowany na wiele, mniej lub bardziej sformalizowanych sposobów, 
- prawnie regulowana aktywność wewnętrznych organów nadzoru klastrowego wynika bezpośrednio ze specyfiki formy organizacyjno-prawnej koordynatora klastra oraz jego organów kontroli i władzy (np. w stowarzyszeniach - komisja rewizyjna, walne zebranie członków, zarząd; z kolei w fundacjach - rada fundacji, fundator, zarząd fundacji),

- $\quad$ system nadzoru klastrowego powinien być adekwatny do potrzeb i możliwości klastra,

- ustalone zasady nadzoru klastrowego powinny kompleksowo regulować relacje pomiędzy interesariuszami wewnętrznymi i zewnętrznymi klastra, wzmacniając zaangażowanie na rzecz ich przestrzegania,

- proces wyboru członków poszczególnych organów władzy i nadzoru w klastrze powinien być otwarty i transparentny, sami zaś kandydaci kompetentni, niezależni i samodzielni, odpowiedzialni za podejmowane działania, tak by wzmacniali zaufanie do ukonstytuowanych organów władzy,

- bardziej zróżnicowana grupa osób z różnych środowisk (biznesu, nauki, administracji, otoczenia biznesu), pełniąca funkcje w poszczególnych organach władzy i nadzoru w klastrze, zwiększa gwarancje, że nadzór klastrowy będzie wykonywany obiektywnie i bezstronnie,

- podstawowe, respektowane w klastrze zasady nadzoru klastrowego powinny być komunikowane otoczeniu m.in. poprzez stronę internetową klastra i/lub jego koordynatora,

- koordynator klastra powinien opracować zestaw mierników monitoringu i ewaluacji wdrażania strategii rozwoju klastra,

- nadzór klastrowy powinien być traktowany jako element prawnej, ekonomicznej, etycznej, społecznej i ekologicznej odpowiedzialności w relacjach intrai interklastrowych.

Warunkiem sprawnego działania klastra jest m.in. przestrzeganie zasad nadzoru klastrowego i kształtowanie odpowiedniego poziomu bezpieczeństwa ekonomicznego, w szczególności w obszarze zarządzania zasobami i procesami w klastrze. Każdy aktywnie działający koordynator klastra, zarówno indywidualnie, jak i zespołowo, niemalże każdego dnia dąży do maksymalizacji tego typu bezpieczeństwa, dla przykładu poprzez identyfikację źródeł finansowania, rozwój klastrowego łańcucha wartości, identyfikację nowych partnerów biznesowych w charakterze członków i inwestorów strategicznych. Jednakże satysfakcjonujące zaspokojenie podstawowych potrzeb w tym zakresie nastręcza wielu nowych trudności i wyzwań w zarządzaniu klastrem, wymagając permanentnego doskonalenia.

Problematyka nadzoru klastrowego i bezpieczeństwa ekonomicznego klastra to wciąż nowe i aktualne problemy badawcze, które nie są szczegółowo rozpoznane na gruncie doświadczeń polskich i zagranicznych klastrów i prezentowane w literaturze naukowej. Tym samym artykuł z założenia ma stanowić źródło inspiracji do dalszego pogłębiania wiedzy w tym obszarze, a także podstawę do dyskusji i szerszej refleksji o wieloaspektowości procesu zarządzania klastrem. 
Bogusław Bembenek

\section{Literatura}

Badak M., 2010, Bezpieczeństwo w aspekcie interesów ekonomicznych państwa, Przegląd Bezpieczeństwa Wewnętrznego, tom 2, nr 2, s. 138-146.

Bobrow D.B., Haliżak E., Zięba R. (red.), 1997, Bezpieczeństwo narodowe i międzynarodowe u schytku $X X$ wieku, Wydawnictwo Naukowe Scholar, Warszawa.

Dube F.N., Haijuan Y., Lijun H., 2015, The role of cluster governance in the process of firm internationalization: based on the example of two Malaysian Halal Industrial Parks, Asia-Pacific Social Science Review, no. 15 (1), s. 102-115.

Dziekański P., 2014, Bezpieczeństwo ekonomiczne wyzwaniem wspótczesnego regionu - próba oceny syntetycznej, Kultura bezpieczeństwa. Nauka - Praktyka - Refleksje, tom 16, s. 121-140.

Ebbekink M., 2017, Cluster governance: A practical way out of a congested state of governance plurality, Environment and Planning C: Politics and Space, vol. 35, no. 4, s. 621-639.

Frączek D., Kryjom P., 2016a, Standardy zarządzania klastrem, PARP, Warszawa.

Frączek D., Kryjom P., 2016b, Weryfikacja standardów zarządzania w wybranych klastrach - edycja 2015, PARP, Warszawa.

Herdan A., 2007, Przestanki i warunki funkcjonowania nadzoru korporacyjnego, Zeszyty Naukowe Wyższej Szkoły Ekonomicznej w Bochni, nr 6, s. 27-45.

Kępka B., Kacperek D., 2017, Wdrażanie standardów zarządzania klastrem. Poradnik dla koordynatorów, PARP, Warszawa.

Klepczarek E., 2016, Nadzór korporacyjny a wyniki przedsiębiorstw: problem metodologii badań, Myśl Ekonomiczna i Polityczna, nr 4(55), s. 87-116.

Knop L., 2013, Zarzadzanie klastrem: koncepcje, strategie, modele, Wydawnictwo Politechniki Śląskiej, Gliwice.

Krzysztofek A., 2012, Teoretyczne aspekty funkcjonowania nadzoru korporacyjnego, Zarządzanie i Finanse, vol. 1, nr 4, s. 331-347.

Księżopolski K.M., 2011, Bezpieczeństwo ekonomiczne, Dom Wydawniczy ELIPSA, Warszawa.

Kuciński A., 2013, Rada nadzorcza w systemie nadzoru korporacyjnego, Zeszyty Naukowe Uniwersytetu Przyrodniczo-Humanistycznego w Siedlcach. Administracja i Zarządzanie, nr 98, s. 223-234.

Leszczyński M., 2016, Bezpieczeństwo ekonomiczne w dobie hiperglobalizacji, Nierówności Społeczne a Wzrost Gospodarczy, nr 47, s. 82-90.

Lund-Thomsen P., Pillay R.G., 2012, CSR in industrial clusters: an overview of the literature, Corporate Governance: The International Journal of Business in Society, vol. 12, no. 4, s. 568-578.

Mikhaylov A.S., 2013, Cluster governance in the framework of cluster social responsibility, [w:] The Strategies of Modern Science Development, Science Book Publishing House, Yelm.

Piotrowski M., 2015, Standardy zarzadzania klastrem, PARP, Warszawa.

Plecka M., 2014, Personalny wymiar bezpieczeństwa ekonomicznego, Studia i Prace Wydziału Nauk Ekonomicznych i Zarządzania, nr 35, tom 2, s. 183-194.

Plecka M., Rychły-Lipińska A., 2013, Istota bezpieczeństwa ekonomicznego państwa - aspekty teoretyczne, [w:] Wybrane problemy bezpieczeństwa, red. A. Urbanek, Wydawnictwo Społeczno-Prawne, Słupsk.

Schretlen J-H., Dervojeda K., Jansen W., Schaffmeister B., 2011, Uncovering Excellence in Cluster Management, PwC, Amsterdam.

Stępień M., 2016, Nadzór korporacyjny - perspektywa międzynarodowa, Studia Ekonomiczne. Zeszyty Naukowe Uniwersytetu Ekonomicznego w Katowicach, nr 271, s. 222-231.

Walczak W., 2012, Nadzór korporacyjny w spółkach z udziałem kapitałowym samorzadu terytorialnego, Współczesne Zarządzanie, nr 3, s. 191-200.

Węgrzyńska M.A., 2015, Identyfikacja bezpieczeństwa ekonomicznego w literaturze i regulacjach prawnych, Prace Naukowe Uniwersytetu Ekonomicznego we Wrocławiu, nr 390, s. 261-272. 
Żabski Ł., 2013, Kodeks dobrych praktyk jako narzędzie doskonalenia nadzoru korporacyjnego, Prace Naukowe Akademii im. Jana Długosza w Częstochowie, zeszyt VII, s. 127-141.

\section{Źródla internetowe}

Berthinier-Poncet A., 2013, Cluster governance and institutional dynamics. A comparative analysis of French regional clusters of innovation, LIRSA research laboratory, Paris, https://emnet.univie. ac.at/uploads/media/Berthinier_Poncet.pdf (10.06.2017).

http://odpowiedzialnybiznes.pl/hasla-encyklopedii/iso-26-000/ (10.06.2017).

Werf R., 2015, Cluster governance in the Medical Cluster of Rotterdam. About how and by whom the Medical Cluster of Rotterdam is organized and governed in response to main global and local cluster dilemmas and challenges, Radboud University Nijmegen, http://theses.ubn.ru.nl/bitstream/ handle/123456789/3968/Werf\%2C\%20Roos\%20van\%20der.pdf?sequence=1 (12.06.2017). 